Pedro Fernando da Costa Vasconcelos

\section{Yellow fever in Brazil: thoughts and hypotheses on the emergence in previously free areas}

\section{Febre amarela no Brasil: reflexões e hipóteses sobre a emergência em áreas previamente livres}

\begin{abstract}
This article describes and discusses factors associated to the reemergence of yellow fever and its transmission dynamics in the states of São Paulo (Southeastern Brazil) and Rio Grande do Sul (Southern) during 2008 and 2009. The following factors have played a pivotal role for the reemergence of yellow fever in these areas: large susceptible human population; high prevalence of vectors and primary hosts (non-human primates); favorable climate conditions, especially increased rainfall; emergence of a new genetic lineage; and circulation of people and/or monkeys infected by virus. There is a need for an effective surveillance program to prevent the reemergence of yellow fever in other Brazilian states.
\end{abstract}

DESCRIPTORS: Yellow Fever, epidemiology. Disease Outbreaks. Epidemiologic Factors. Zoonoses. Communicable Diseases, Emerging. Epidemiologic Surveillance.

\section{RESUMO}

São descritos e discutidos fatores associados a emergência e dinâmica da transmissão da febre amarela nos estados de São Paulo e Rio Grande do Sul nos anos de 2008 e 2009. A interação dos seguintes fatores foi fundamental para a emergência de febre amarela nesses estados: a grande população humana suscetível; a elevada prevalência de vetores e hospedeiros (primatas não humanos); condições climáticas favoráveis, sobretudo o excesso de chuvas no verão; a emergência de uma nova linhagem viral; e a circulação de pessoas ou macacos infectados em fase virêmica. Apenas um programa eficiente de vigilância pode prevenir ocorrências similares nesses estados brasileiros.

DESCRITORES: Febre Amarela, epidemiologia. Surtos de Doenças. Fatores Epidemiológicos. Zoonoses. Doenças Transmissíveis Emergentes. Vigilância Epidemiológica. 


\section{INTRODUCTION}

Yellow fever, the original hemorrhagic fever, was one of the greatest scourges of mankind. Historical epidemics of this disease occurred between the eighteenth and twentieth centuries in many countries in the Americas, Africa, and Europe. ${ }^{13}$ With the introduction of yellow fever 17D vaccine in the late $1930 \mathrm{~s}^{14}$ and campaigns for the eradication of Aedes aegypti mosquito, urban epidemics of yellow fever have dropped dramatically and outbreaks have been confined to wilderness areas with transmission mostly by Haemagogus janthinomys in the Americas and Aedes africanus in Africa. ${ }^{22}$ Despite that, it is estimated that 200,000 cases of yellow fever occur annually with 30,000 deaths, and underreporting of cases is the rule rather than the exception. ${ }^{9}$

The basic question concerning yellow fever in Brazil and other endemic countries is: why are there still so many cases despite the fact that a low-cost, effective vaccine has been available for more than 70 years? Other puzzling issues should be addressed, particularly in Brazil: a) recent occurrence of epidemics and epizootics in areas in which there were no cases for decades (Figure); b) the reasons why viral spread is repeating the same path as in the 1940s and moving towards the coast; and c) why this is a reemerging disease despite improved surveillance, easy access to vaccine and recent environmental changes with high rates of deforestation. These are challenging issues as many factors are involved and they are addressed in the present article.

\section{YELLOW FEVER PARADIGMS}

\section{Periodic epizootic outbreaks}

Historically, epizootic outbreaks have been reported in Brazil (and in other endemic countries as well) from time to time. These outbreaks vary from region to region. In the 1940s (Figure), there was a sequential shift of yellow fever virus (YFV) from Central-West Brazil (state of Mato Grosso) to the coast with the disease being reported in the Northeast (state of Bahia), Southeast (states of Minas Gerais, Espírito Santo, and São Paulo), and the Southern. ${ }^{13}$ In the Amazon region and in other endemic areas in Brazil, epizootic outbreaks have been reported every five to seven years. ${ }^{18}$ This periodicity is likely due to renewal of non-human primate populations essential for viral amplification, which does not occur with vector population alone (Haemagogus and Sabethes mosquitoes) even considering the possibility of transovarial or vertical transmission.

A good example is the state of Goiás (Central-West Brazil). The most recent epizootics and epidemics of yellow fever in Goiás occurred in 1972-1973, 1980, 1988, 2000, and 2007-2008..$^{11,15,17,18}$ These occurrences are part of a paradigm in which yellow fever virus periodically spreads via epizootic outbreaks to continuous and contiguous areas, following the movements of nonhuman primates and natural watercourses. ${ }^{7,8,13}$

However, the same is not expected in unaffected areas. Yellow fever virus is usually introduced by probably one of two ways. First, people who are viremic or in an incubation period go to areas with high population densities of vectors/transmitters and vertebrate hosts. Once the virus is established in the area, an explosive viral transmission via vectors occurs among non-human primates without natural immunity, resulting in an almost total elimination of these monkey populations, which has been demonstrated in a molecular study with more than 70 strains of yellow fever virus isolated in Brazil $^{20}$ and in the recent epidemic registered in the states of Rio Grande do Sul and São Paulo. ${ }^{12}$ Indeed, molecular analysis showed that yellow fever virus isolates from Marajó island in the Northern state of Pará ${ }^{16}$ were identical to yellow fever viral strains found in Goiás and Bahia. ${ }^{15}$ Since these two areas where infection probably occurred were more than 2,000 km apart (Figure), viral spread through monkeys is not possible, and only viremic humans with oligosymptomatic or even asymptomatic infections could have carried these yellow fever virus strains. ${ }^{20}$

Another way is illegal traffic of wild animals. Animal traffickers are known to use illegal roads or means that are generally of more difficult access, which might lead to the introduction of the virus into areas where, when conditions are favorable, natural zoonotic transmission cycle may occur.

\section{Favorable climate conditions}

Although it is difficult to measure and evaluate the impact of climate conditions on the onset and magnitude of an outbreak or zoonotic epidemic of yellow fever, a study conducted in the state of Goiás during the 2000 epidemic showed that climate conditions played a crucial role in determining its magnitude. ${ }^{15} \mathrm{~A}$ 10-year survey of official data recorded between 1991 and 2000 by the Instituto Nacional de Meteorologia (INMET - National Institute of Meteorology) showed that temperatures increased and rainfall index was much higher in 2000 than the average for 1990 to 1999. This suggests that increased rainfall favored mosquito proliferation and high temperatures promoted viral spread and transmission. ${ }^{15}$

\section{Wildlife vectors of yellow fever}

There are two major mosquito vectors for zoonotic yellow fever in Brazil nowadays, $\mathrm{Hg}$. janthinomys and $\mathrm{Hg}$. leucocelaenus. ${ }^{18,19}$ The former is the main vector of yellow fever in endemic areas (where vaccine is 

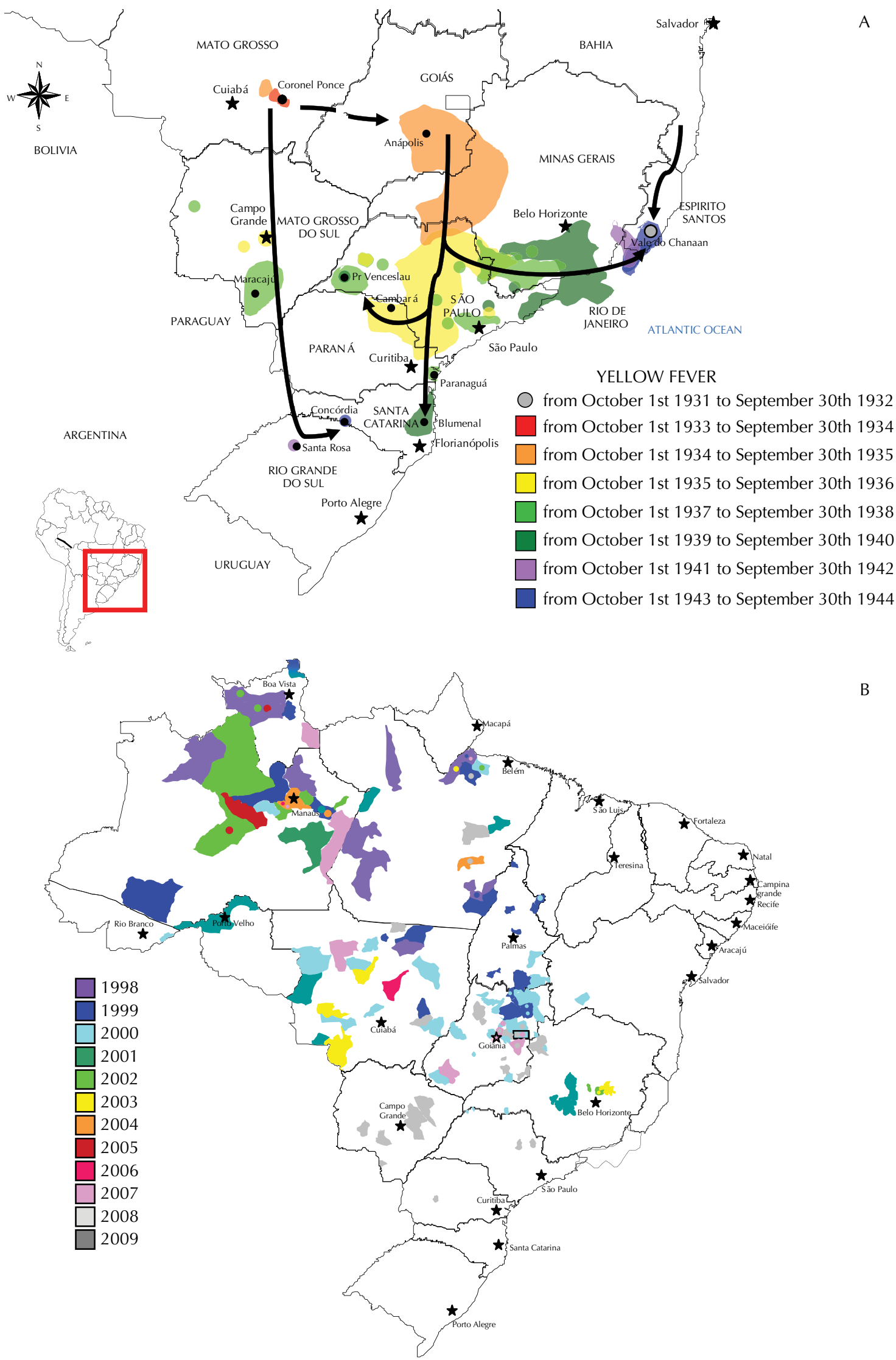
recommended) and in the state of São Paulo; ${ }^{3-5,13}$ but it has not been found in southern Brazil. It is a mosquito with strict host specificity for wild animals, indicating that virus transmission occurs within or near forested areas. The latter has a more broad host range; it sometimes leaves the forest and can be found at ground level in areas surrounding woods or forested groves common in southern Brazil. ${ }^{6}$ In 2001 YFV was isolated from $\mathrm{Hg}$. leucocelaenus during an epizootic outbreak in the mission areas in the Southern state of Rio Grande do Sul, 40 years after the last report of yellow fever in this region. ${ }^{1,10,19}$ More recently, during the 2008 and 2009 outbreaks, it was commonly captured infected in the municipalities of Rio Grande do Sul and São Paulo, where human cases and epizootic cases in monkeys (Alouatta caraya) were reported. ${ }^{2,12}$ These findings support the hypothesis that this species plays a role in yellow fever transmission in Brazilian southern areas, especially due to absence of $\mathrm{Hg}$. janthinomys.

\section{Non-human primates}

Monkeys are the primary vertebrate hosts of YFV and play an important role in the amplification of viral transmission. A single viremic monkey can be an infection source for tens or hundreds of mosquito vectors, greatly increasing the rate of disease transmission. Since Haemogogus species preferably feed on primates, their role in the infection of mosquito vectors, including minimal infection rate, can be measured and is a very important marker of mosquito infection. ${ }^{21}$

\section{ON THE REEMERGENCE OF YELLOW FEVER IN SOUTHERN BRAZIL}

\section{Susceptible population}

Yellow fever vaccination in Rio Grande do Sul (since 2001) and São Paulo are carried out only in districts where epizootic outbreaks occurred and in adjacent municipalities within a safety margin. Hence, most human population susceptible to the virus has not been vaccinated. It suggests that the circulating of YFV among susceptible human population can increase the risk of arbovirus transmission to humans, and especially to monkeys, as it was observed in the states of Rio Grande do Sul in 2008 and Sao Paulo in 2009. Following the traumatic events of these last epidemics, rigorous surveillance and vaccination programs should be in place.

\section{Large populations of vectors and primary hosts}

High population densities of yellow fever vectors and their primary hosts were certainly present in Rio Grande do Sul and São Paulo states. This was evidenced especially in Southern Brazil, where dozens of outbreaks were confirmed by specific examination of mosquitoes and howler monkeys found dead, sick, or captured in transmission areas. Considering that each viremic monkey can infect hundreds of mosquitoes, it is easy to understand the dynamics of viral transmission in Rio Grande do Sul: as epizootics occurred, several howler monkeys died, and hundreds, perhaps thousands, of $\mathrm{Hg}$. leucocelaenus became infected, leading to epizootic maintenance, including through transovarial transmission. ${ }^{8}$ As the virus was carried by humans and/or viremic monkeys and spread to other areas, new cases and epizootics were reported. Interestingly, this pattern supports the transmission paradigm in epizootic outbreaks.

The respect for animals, particularly howler monkeys, caused this population of animals to greatly increase in the South, creating favorable conditions to the maintenance of a native transmission cycle of yellow fever. The reintroduction of YFV in 2000 in the Rio Grande do Sul was probably due a silent cycle. ${ }^{19}$ It is therefore possible that during the years that preceded the most recent outbreak, an intense viral multiplication in vectors had been going on, which was crucial for viral spread among vectors. This fact was pivotal for the explosion of yellow fever transmission in Rio Grande do Sul and São Paulo states.

\section{Favorable climate conditions}

There have been recently major climate changes especially in the state of Rio Grande do Sul, resulting in intense and prolonged conditions alternating between rainfall and drought. A detailed study of humidity, temperature, and rainfall patterns is imperative to explore whether there were unusual conditions during the years with yellow fever case reports. Nevertheless, it is likely that recent climate alterations may have significantly contributed to the reemergence of yellow fever in that state. A comparison between Goiás ${ }^{15}$ and Rio Grande do Sul ${ }^{2}$ show that the epizootics and occurrence of cases were very similar; therefore it seems likely that climate factors have also played an important role in transmission.

\section{Emergence of a new viral lineage}

In the 2008-2009 epidemic in Rio Grande do Sul ${ }^{2}$ and São Paulo, ${ }^{12}$ a new viral lineage (genotype 1E) emerged from the previously described lineage genotype $1 \mathrm{D} .{ }^{20}$ Molecular evidence indicates that the emergence of this new genetic lineage follows a pattern described for several viruses with a "boom-and-bust cycle," where the current lineage originates from the previous lineage and replaces it. ${ }^{23}$ Lineage $1 \mathrm{D}$, which has emerged and circulated in Brazil since 1998 in the state of Pará (Northern Brazil), caused yellow fever epidemics until 2007. ${ }^{15,16,19,20}$ It later gave rise to lineage $1 \mathrm{E}$, which replaced it, as reported by Sousa et $\mathrm{al}^{12}$ and Cardoso et al. ${ }^{2}$ 


\section{Circulation of yellow fever virus and viremic people}

The circulation of YFV and people movement within affected states, mostly in Rio Grande do Sul state, allows us to partially understand the virus circulation dynamics. The virus found in both states is identical. People movement and infected monkey trafficking is a compelling explanation for yellow fever reemergence in areas that have been unaffected by viral circulation for more than 40 years and that are about 1,000 km away from each other.

\section{FINAL CONSIDERATIONS}

A combination of five factors is likely to be associated with the reemergence of yellow fever in southern and southeastern Brazil (recent epizootics and epidemics): exposure of a susceptible human population; high density of vectors and primary hosts (non-human primates); favorable climate conditions, especially increased rainfall; emergence of a new genetic lineage; and circulation of people and/or infected monkeys. There is a need for an effective surveillance program to prevent the reemergence of yellow fever in other Brazilian states. 


\section{REFERENCES}

1. Cardoso JC, Corseuil E, Barata JMS. Culicinae (Diptera, Culicidae) ocorrentes no estado do Rio Grande do Sul, Brasil. Rev Bras Entomol. 2005;49(2):275-87. DOI:10.1590/S0085-56262005000200013

2. Cardoso JC, Almeida MAB, Santos E, Fonseca DF, Sallum MAM, Noll CA, et al. Yellow fever virus isolation from Haemagogus leucocelaenus and Aedes serratus mosquitoes in epizootic areas, northwestern Rio Grande do Sul State, Brazil, 2008. Emerg Infect Dis. 2010;16(12): In Press.

3. Dégallier N, Travassos da Rosa APA, Vasconcelos PFC, Travassos da Rosa ES, Rodrigues SG, Sa Filho GC, et al. New entomological and virological data on the vectors of sylvatic yellow fever. I Brazilian Assoc Advanc Sci. 1992;44(2/3):136-42.

4. Dégallier N, Travassos da Rosa APA, Herve JP, Travassos da Rosa JFS, Vasconcelos PFC, Mangabeira da Silva CJ, et al. A comparative study of yellow fever in Africa and South America. I Brazilian Assoc Advanc Sci. 1992;44(2/3):143-161.

5. Forattini OP. Culicidologia médica: identificação, biologia, epidemiologia. São Paulo: EDUSP; 2002. v.2.

6. Kumm HW, Cerqueira NL. The role of Aëdes leucocelaenus in the epidemiology of jungle yellow fever. Bull Entomol Res. 1951;42:195-200. DOI: $10.1017 /$ S0007485300025281

7. Mondet B, Travassos da Rosa APA, Vasconcelos PFC. Les risques d'épidemisation urbaine de la fievre jaune au Brésil par les vecteurs de la dengue. Bull Soc Path Ex. 1996;89(2):107-14.

8. Mondet B, Vasconcelos PFC, Travassos da Rosa APA, Travassos da Rosa ES, Rodrigues SG, Travassos da Rosa JF, et al. Isolation of yellow fever virus from nulliparous Haemagogus (Haemagogus) janthinomys in Eastern Amazonia. Vector Borne Zoonotic Dis. 2002;2(1):4750. DOI:10.1089/153036602760260779

9. Monath TP. Yellow fever - update. Lancet Infect Dis. 2001;1(1):11-20. DOI:10.1016/S14733099(01)00016-0

10. Nobre A, Antezana D, Tauil PL. Febre amarela e dengue no Brasil: epidemiologia e controle. Rev Soc Bras Med Trop. 1994;27 (Suppl 3):59-66.

11. Pinheiro FP, Travassos da Rosa APA, Moraes MA, Almeida Neto JC, Camargo S, Filgueiras FP. An epidemic of yellow fever in Central Brazil, 19721973. I. Epidemiological studies. Am J Trop Med Hyg. 1978;27(1 Pt 1):125-32.
12. Souza RP, Foster PG, Sallum MA, Coimbra TL, Maeda AY, Silveira VR, et al. Detection of a new yellow fever virus lineage within the South American genotype I in Brazil. J Med Virol. 2010;82(1):175-85. DOI:10.1002/ jmv. 21606

13. Strode GK. 1951. Yellow fever. New York: McGrawHill; 1951.

14. Theiler M, Smith HH. Use of yellow fever modified by in vitro cultivation for human immunization. J Exp Med. 1937;65(6):787-800. DOl:10.1084/jem.65.6.787

15. Vasconcelos PFC, Costa ZG, Travassos da Rosa ES, Luna EJ, Rodrigues SG, Barros VL, et al. An epidemic of jungle Yellow fever in Brazil, 2000. Implications of climatic alterations in disease spread. J Med Virol. 2001;65(3):598-604. DOI:10.1002/jmv.2078

16. Vasconcelos PFC, Travassos da Rosa APA, Rodrigues SG, Travassos da Rosa ES, Monteiro HAO, Cruz ACR, et al. Yellow fever in Pará State, Amazon region of Brazil, 1998-1999. Entomological and epidemiological findings. Emerg Infect Dis. 2001;7(3):565-9. DOI:10.3201/eid0703.010338

17. Vasconcelos PFC. Febre amarela: reflexões sobre a doença, as perspectivas para o século XXI e o risco da reurbanização. Rev Bras Epidemiol. 2002;5:244-58. DOI:10.1590/S1415-790X2002000300004

18. Vasconcelos PFC. Febre amarela. Rev Soc Bras Med Trop. 2003;36(2):275-93. DOI:10.1590/S003786822003000200012

19. Vasconcelos PFC, Sperb AF, Monteiro HAO, Torres MAN, Sousa MRS, Vasconcelos HB, et al. Isolations of yellow fever virus from Haemagogus leucocelaenus in Rio Grande do Sul State, Brazil. Trans Roy Soc Trop Med Hyg. 2003;97(1):60-62. DOI:10.1016/S00359203(03)90023-X

20. Vasconcelos PFC, Bryant JE, Rosa TP, Tesh RB, Rodrigues SG, Barrett AD. Genetic divergence and dispersal of yellow fever virus, Brazil. Emerg Infect Dis. 2004;10(9):1578-84.

21. Walter SD, Hildreth SW, Beaty BJ. Estimation of infection rates in populations of organisms using pools of variable size. Am J Epidemiol. 1980;112(1):124-8.

22. World Health Organization. Prevention and control of yellow fever in Africa. Geneva; 1986.

23. Zanotto PM, Gould EA, Gao GF, Harvey PH, Holmes EC. Population dynamics of flaviviruses revealed by molecular phylogenies. Proc Nat Acad Sci USA. 1996;93(2):548-53. DOI:10.1073/pnas.93.2.548

The study was partially supported by Instituto Nacional de Ciência e Tecnologia for Viral Hemorrhagic Fevers, by the project Conselho Nacional de Desenvolvimento Científico e Tecnológico/ Coordenação de Aperfeiçoamento de Pessoal de Nível Superior/ Fundação de Amparo à Pesquisa do Estado do Pará (CNPq/CAPES/FAPESPA - Grant no 573739/2008-0).

The author declare that there are no conflicts of interests. 